\title{
Sustainable Campus Through Solid Waste Minimization Strategies Case study: Universitas Agung Podomoro in Indonesia
}

\author{
Alifia Intan Safitri ${ }^{1}$, Elsa Try Julita Sembiring ${ }^{1}$, Maria Prihandrijanti ${ }^{1}$ \\ ${ }^{1}$ Environmental Engineering Universitas Agung Podomoro, Indonesia \\ fhiaintan@gmail.com
}

\begin{abstract}
A large amount of solid waste (SW) generation becomes inevitable for campus due to its population and various activities. Therefore, it is a challenge to develop and implement an SW minimization plan to encourage sustainable campus practices. This study aimed to develop sustainable strategies to support this plan for Universitas Agung Podomoro (UAP), included evaluating the SW management condition by monitoring the SW generation and surveying the perception and willingness to participate in campus society. The results showed that the SW generation was $52.63 \mathrm{~kg} / \mathrm{day}$ or $0.08 \mathrm{~kg} / \mathrm{person} / \mathrm{day}$. The composition consisted of $32.29 \%$ biodegradable and $67.71 \%$ non-biodegradable. The recycling potential was $61.01 \%$ consisted of $22.28 \%$ composting and $38.73 \%$ recycling. The social survey showed that respondents had positive perceptions about SW minimization. The complete evaluation resulted in the development of strategies to decrease the SW generation rate, increase the recyclable material rate, and increase campus society's participation.
\end{abstract}

(c) 2020 IJBESR. All rights reserved.

Keywords: solid waste management, solid waste minimization, and sustainable campus

\section{Introduction}

The growth of Indonesia's population was followed by an increase in solid waste (SW) generation [1]. Based on the Ministry of Environment and Forestry, SW generation in DKI Jakarta went up to 6,200 tons/day during 2017/2018. The educational institution contributed $0.52 \%$ of the total SW.

Various activities on campus, such as learning, teaching, consuming, and administrating, impact a large amount of SW. The composition of SW on the campus generally consisted of food waste, leaves, wood, paper, plastic, textile, styrofoam, metal, glass, rubber, and others that potentially recycled [2]. For instance, the recycling potential of $\mathrm{SW}$ at the Universitas Putra Indonesia in Padang was 79.11\% [2], and the Universitas Indonesia was $51.33 \%$ [3]. The same phenomenon occurred in America, where Georgetown University has recycled up to $45 \%$ and Rutgers University's $67 \%$ of total SW per year [4].

Campuses should initiate their own sustainable SW management plans due to their ethical and legal responsibilities about environmental actions. The SW management plan should have transformed into a new paradigm that emphasizes SW minimization by Reduce, Reuse, and Recycle (3R). A useful new paradigm of SW management needs a complete understanding of the generation amount of SW in the first place. Its plan is prepared based on this 3R concept and the targets determined within the scope of the zero SW principle [5]. The concept of $3 \mathrm{R}$ was intended to be implemented due it would prevent the SW from being disposed of into the environment. However, its implementation depended oncampus management's commitment [6]. 
The contrast between the old and new paradigm of SW management was shown in Fig. 1.

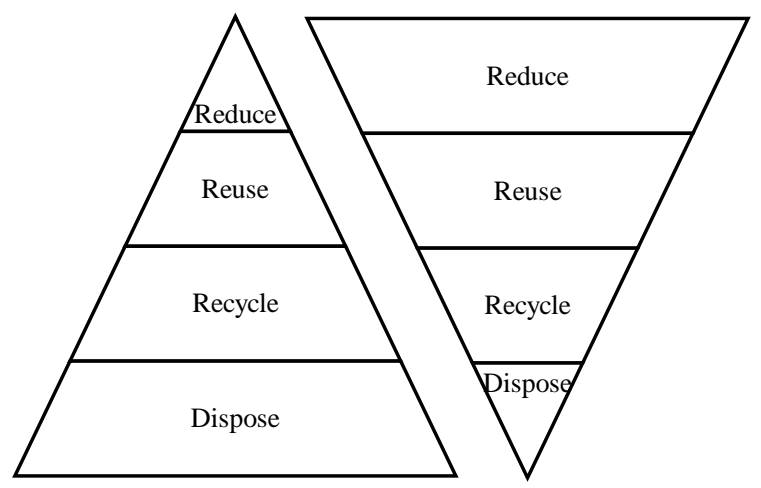

(a)

(b)

Source: Damanhuri E, Padmi T (2015) [14] Figure 1. (a) Old paradigm SW management,

(b) New paradigm SW management

The old (traditional) paradigm is focused on SW collecting and disposing. In comparison, the new paradigm significantly put effort into minimizing SW from the beginning [7]. In essence, it encourages society to set the highest value on source reduction and extended producer responsibility, then focuses on waste conversion processes that recover materials and energy from wastes and/ or the production of compost.

Therefore, the development and implementation of an SW management plan, which includes proactive initiatives, has prime importance to initiate sustainable campus practices. The new paradigm SW management will be successful, accompanied by community (campus society) participation because SW management knowledge is strongly correlated with its activity. Education can support actions and generate awareness, concern, and recognition of the effect of activities [8]. The activities like SW minimization is expected on its participation.

The SW minimization is an indicator of the green campus concept according to the UI
Greenmetric World University Ranking [9]. It is a program in implementing a green campus concept for universities in the world, initiated by Universitas Indonesia. Simultaneously, the green campus concept aims to realize a sustainable campus through three aspects: economics, social, and environment [10]. An example of a campus that has implemented that concept in SW management is Universitas Diponegoro [11]. The sustainable campus principle also supports Sustainable Development Goals (SDGs) number 12, "Responsible Consumption and Production," which halves SW's amount in 2030. A comprehensive SW management, specifically, is one of the major components in achieving campus institutional sustainability [5]. For example, Australian National University's (ANU) Green, Sustainability Office, and ANU students researched how to recycle food waste from the kitchens using the "HotRot" digester, which converts it into organic matter without releasing harmful emissions to the environment [22].

Universitas Agung Podomoro (UAP) is one of the newly established campuses that apply the old paradigm SW management concept. It was indicated from the current SW management that not segregated and directly transferred to the SW collection room owned by building management. Next, the collected SW of the building tenants would be transported to the final disposal. Therefore, it was necessary to develop sustainable strategies that would support the SW minimization plan for UAP based on current conditions: SW generation, its compositions, and social perception about SW minimization.

\section{Material and Methods}

The following three steps to developing sustainable strategies in SW minimization: 1. scoping, 2. collecting data, 3. evaluating data. In the first step, the source of SW generation was assessed by visit each point. The second 
stage was conducted by interviewing the administrators responsible for SW management on the campus, collecting secondary data, and monitoring SW generation for 14 days, then analyzing its composition and recycling potential. A questionnaire survey was also conducted to understand the campus society's perception and willingness to participate in SW minimization. For the last stage, the current SW management and social perception condition was assessed to consider some steps required to minimize SW at UAP.

The study presented in this paper can contribute to literature since studies with similar integrated evaluation methodology were still few.

\subsection{Scoping}

UAP was located at Podomoro City, West Jakarta, Indonesia. It was established in 2013. The campus area is 7,593.28 $\mathrm{m} 2$, and it has 9 study programs. In 2020, the numbers of campus society are 959 students and 235 lecturers and administrative staff.

UAP was a place for learning and many activities, so the SW generation came from some points: 23 classrooms; 9 laboratories; 18 lecturers and administration rooms; canteen; kitchens; toilets; and corridors.

The SW storage container has consisted of two types of capacity 5 liters or 80 liters located depending on the amount of its generation throughout classrooms, lecturers and administration rooms, kitchens, canteen, toilets, and corridors. Both were "level-1" storage due collected the SW from the sources. Next, they will be collected in trash bags capacity of 100120 liters as a "level-2" storage located in a room of $(8 x 4)$ meters at UAP. Next, transfer to the SW collecting room of $(7 \times 5)$ meters owned by building management to be then transported to the final disposal by permitted.

\subsection{Collecting Data}

a. Interview

It was begun by interviewing the administrators responsible for SW about what kind of SW generated, how frequently the SW was collected, the SW management steps, and issues related to $\mathrm{SW}$ management on the campus.

\section{b. Daily SW Generation Monitoring}

The SW sampling method referred to SNI 193964-1994 and had been carried out for 14 days. The daily SW sample was evaluated using plastic bags, sampling boxes 40 liters, scales, and a note. Its composition was then analyzed by segregating and weighing each component to calculate the recycling potential of recyclable waste. Studies on the recycling potential of food waste by composting were not included in this study.

The formula used in calculating SW generation and its composition:

1) $S W$ generation $(\mathrm{kg} /$ day $)$ :

$=\frac{\text { waste }(\mathrm{kg})}{\text { numbers of sampling days (day) }}$

2) SW generation $(\mathrm{kg} /$ person/day):

waste $(\mathrm{kg} /$ day $)$

$=\overline{\text { numbers of waste producers (person) }}$

3) SW Composition (\%):

$=\frac{\text { waste } A(\mathrm{~kg})}{\text { total waste }(\mathrm{kg})} \times 100 \%$

with:

$\mathrm{A}=$ types of $\mathrm{SW}$

c. Survey of Social Perception and Willingness to Participation

The successful SW management strategy could not be separated by social participation [12]. To understand the campus society's current awareness, an online questionnaire was conducted among 92 respondents consisting of students, lecturers, and administrative staff through random sampling in April 2020.

Data collected was analyzed using a frequency distribution table to describe how often each variable's value occurred on several observed objects [13]. The chi-square method with "IBM SPSS Statistics 23" software was applied to determine the effect or relationship of a variable with the thing observed [6]. 
Decision making of the chi-square test results was determined by two statements:

1) If the significance value of chi-square test<critical value (0.05), the $\mathrm{H}_{\mathrm{o}}$ was rejected and $\mathrm{H}_{\mathrm{a}}$ was accepted (there was a relationship between variables $x$ and $y$, or the variable $x$ could affected the variable $y$ ).

2) If the significance value of chi-square test>critical value $(0.05)$, the $\mathrm{H}_{\mathrm{o}}$ was accepted and $\mathrm{H}_{\mathrm{a}}$ was rejected (there was no relationship between the variables $x$ and $y$, or the variable $\mathrm{x}$ not affect the variable $\mathrm{y}$ ).

\subsection{Evaluating Data}

The complete data about SW management and social perception would be evaluated to obtain the appropriate sustainable strategies applied on the campus that including steps per stage.

\section{Results and Discussions}

The findings showed that the SW management practices pointed to administrators responsible for handling the SW. On the other hand, it showed neither a new hierarchical paradigm nor the holistic approach of SW management was implemented on the campus. There was no segregation either at the source or in the collection room. The SW was collected from its source twice a day by a cleaning service (CS) and transferred to the collection room. Then, the collected SW during a day would be transferred to the main collecting station own by building management in the afternoon. The SW collected from all tenants would be transported directly to final disposal by permitted transporter at night.

\subsection{SW generation at UAP}

The SW could be classified into various types depending on their sources. Tab. 1 showed the details of its general classification.
Table 1. General classification of SW at UAP

\begin{tabular}{|c|c|c|}
\hline No. & Sources & Type of SW \\
\hline 1. & Classrooms & $\begin{array}{l}\text { Office paper, styrofoam, } \\
\text { plastic bottles and cups, } \\
\text { carton, packaging, plastic } \\
\text { bags, tissue, etc. }\end{array}$ \\
\hline 2. & $\begin{array}{l}\text { Lectures and } \\
\text { administration rooms }\end{array}$ & $\begin{array}{l}\text { Office paper, styrofoam, } \\
\text { plastic bottles and cups, } \\
\text { packaging, plastic bags, } \\
\text { tissue, etc. }\end{array}$ \\
\hline 3. & Kitchens & $\begin{array}{l}\text { Food waste, leaves, } \\
\text { packaging, plastic bags, } \\
\text { cardboard, etc. }\end{array}$ \\
\hline 4. & Canteen & $\begin{array}{l}\text { Food waste, leaves, } \\
\text { brown paper, carton, } \\
\text { packaging, plastic bags, } \\
\text { styrofoam, etc. }\end{array}$ \\
\hline 5. & Toilets & Tissue, plastic bags, etc. \\
\hline 6. & Corridors & $\begin{array}{l}\text { Styrofoam, plastic bottles } \\
\text { and cups, carton, } \\
\text { packaging, plastic bags, } \\
\text { tissue, etc. }\end{array}$ \\
\hline
\end{tabular}

Source: (Author, 2020)

The SW generation was one of the essential steps in planning a sustainable SW management strategy at UAP. Daily monitoring was conducted to estimate the temporal variation of SW generation amount on the campus for 14 days. The results showed that the total SW generation per day varies between 0 and 100.54 $\mathrm{kg}$. The daily average $\mathrm{SW}$ generation was 52.63 kg/day. The result was shown in Tab. 2.

Table 2. SW generation at UAP

\begin{tabular}{|c|c|c|}
\hline No. & Day & SW generation (kg) \\
\hline 1. & 1 & 89.61 \\
\hline 2. & 2 & 38.90 \\
\hline 3. & 3 & 76.83 \\
\hline 4. & 4 & 48.50 \\
\hline 5. & 5 & 69.00 \\
\hline 6. & 6 & 13.30 \\
\hline 7. & 7 & 0 \\
\hline 8. & 8 & 77.10 \\
\hline 9. & 9 & 77.69 \\
\hline 10. & 10 & 69.20 \\
\hline 11. & 11 & 62.00 \\
\hline 12. & 12 & 103.54 \\
\hline 13. & 13 & 11.20 \\
\hline 14. & 14 & 0 \\
\hline \multicolumn{2}{|c|}{ Total (kg) } & $\mathbf{7 3 6 . 8 7}$ \\
\hline \multicolumn{2}{|c|}{ Average (kg/day) } \\
\hline
\end{tabular}

Source: (Author, 2020) 
Seen in Tab. 2, the total of SW generation amount during 14 days was $736.87 \mathrm{~kg}$ with the average SW generation of $52.63 \mathrm{~kg} /$ day. Fig. 2 showed the fluctuation of daily SW at UAP.

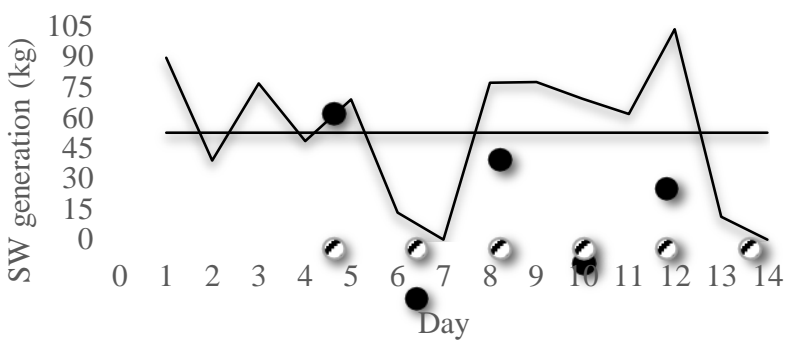

Source: (Author, 2020)

Figure 2. Fluctuation of SW generation during 14 days

The fluctuation showed in Fig. 2 was related to various activities happened. The highest one occurred on the $12^{\text {th }}$-day $(103.54 \mathrm{~kg})$ since it was the first opening day of a minimarket so that impacted to increasing of daily SW. While the least amount was on the $7^{\text {th }}$ and $14^{\text {th }}$-days, due to no activity at UAP.

Events like seminars and workshops contributed the increase of SW until $18.65 \%$. This was indicated by the comparison of daily SW generation without events of $65.16 \mathrm{~kg} /$ day $\left(1^{\text {st }}, 5^{\text {th }}, 8^{\text {th }}, 10^{\text {th }}\right.$ and $11^{\text {th }}$-days $)$ while there were events of $77.31 \mathrm{~kg} /$ day $\left(1^{\text {st }}, 2^{\text {nd }}, 3^{\text {rd }}, 9^{\text {th }}\right.$ and $12^{\text {th }}$ days).

Next, the SW generation per person per day was calculated at $0.08 \mathrm{~kg} /$ person/day. There was no higher education SW generation was determined in SNI S 04-1993-03. The educational institution was only represented by "school" at $0.01-0.02 \mathrm{~kg} /$ person/day. It could be seen the contrast of the amount of SW generation in SNI and the UAP was quite significant. Consumption patterns [14] between students and "college" students could be one of the factor.

Associated to other campuses, the SW generation among other campus was varied. The SW generation per person per day was shown below in Tab. 3 .
Table 3. SW generation from various campuses

\begin{tabular}{|c|l|c|c|}
\hline No. & \multicolumn{1}{|c|}{ Campus } & $\begin{array}{c}\text { SW Generation } \\
\text { Factor } \\
\text { (kg/person/day) }\end{array}$ & Reference \\
\hline 1. & $\begin{array}{l}\text { Universitas Agung } \\
\text { Podomoro }\end{array}$ & 0.08 & This study \\
\hline 2. & $\begin{array}{l}\text { Universitas Putra } \\
\text { Indonesia Padang }\end{array}$ & 0.6271 & {$[2]$} \\
\hline 3. & $\begin{array}{l}\text { Universitas } \\
\text { Indonesia }\end{array}$ & 0.024 & {$[1]$} \\
\hline 4. & Universitas Andalas & 0.12 & {$[15]$} \\
\hline 5. & $\begin{array}{l}\text { Mersin University } \\
\text { Çiftlikkoy Campus }\end{array}$ & 0.08 & {$[5]$} \\
\hline 6. & Gazi University & 0.31 & {$[5]$} \\
\hline 7. & $\begin{array}{l}\text { METU e Ankara } \\
\text { Campus }\end{array}$ & 0.4 & {$[5]$} \\
\hline 8. & $\begin{array}{l}\text { METU - North } \\
\text { Cyprus Campus }\end{array}$ & 0.48 & {$[16]$} \\
\hline 9. & $\begin{array}{l}\text { Universiti } \\
\text { Teknologi MARA }\end{array}$ & 0.47 & $\begin{array}{l}\text { Jordan University } \\
\text { of Science and } \\
\text { Technology }\end{array}$ \\
\hline 10. & 0.37 & \\
\hline
\end{tabular}

Source: (Author, 2020)

Seen in Tab. 3, there were SW generation factor at local and foreign campus. Then, Fig. 3 showed the comparison of SW generation from various campuses.

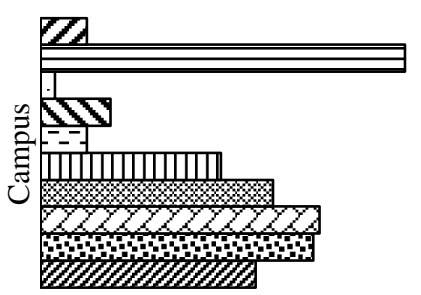

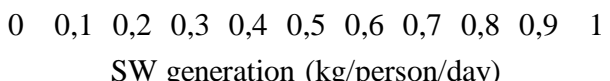

ه Universitas Agung Podomoro

घUniversitas Putra Indonesia Padang

口Universitas Indonesia

QUniversitas Andalas

口Mersin University Çiftlikk€oy Campus

$\square$ Gazi University

$\checkmark$ METU e Ankara Campus

aMETU - North Cyprus Campus

UUniversiti Teknologi MARA

U Jordan University of Science and Technology

Source: (Author, 2020)

Figure 3. Comparison of SW generation from various campuses 
Fig. 3 showed that SW generation per person on some campuses were range $0.02-1.00$ since there were several factor influenced such as: total population, lifestyles, season, and mobility [14]. As seen in Tab. 3, the SW of UAP was below the average. The least SW generation per person was Universitas Indonesia (0.024 $\mathrm{kg} /$ person/day) that already applied SW minimization in Indonesia. According to its area, UAP was the smallest area and the only campus that was part of the main office building. So that, there was no yard SW contributed.

\subsection{Composition of SW at UAP}

The composition of SW was expressed as a percentage $(\%)$ by weight. The composition of SW during the measurement period was shown in Tab. 4.

Table 4. Composition of SW at UAP

\begin{tabular}{|c|l|c|c|}
\hline No. & $\begin{array}{l}\text { Composition } \\
\text { of SW }\end{array}$ & $\begin{array}{c}\text { Average } \\
\text { (kg/day) }\end{array}$ & \%composition \\
\hline Composition by category \\
\hline 1. & $\begin{array}{l}\text { Biodegradable } \\
\text { SW }\end{array}$ & 16.769 & $32.29 \%$ \\
\hline 2. & $\begin{array}{l}\text { Non- } \\
\text { biodegradable } \\
\text { SW }\end{array}$ & 35.155 & $67.71 \%$ \\
\hline Composition by type & \multicolumn{2}{l|}{} \\
\hline 1. & Food waste & 16.617 & $32.00 \%$ \\
\hline 2. & $\begin{array}{l}\text { Plastic bottles } \\
\text { and cups }\end{array}$ & 9.001 & $17.34 \%$ \\
\hline 3. & Tissue & 6.865 & $13.22 \%$ \\
\hline 4. & Carton & 3.226 & $6.21 \%$ \\
\hline 5. & Plastic bags & 2.689 & $5.18 \%$ \\
\hline 6. & Styrofoam & 2.687 & $5.18 \%$ \\
\hline 7. & Cardboard & 2.530 & $4.87 \%$ \\
\hline 8. & HVS paper & 2.387 & $4.60 \%$ \\
\hline 9. & $\begin{array}{l}\text { Snacks } \\
\text { packaging }\end{array}$ & 1.779 & $3.43 \%$ \\
\hline 10. & Brown paper & 1.58 & $3.04 \%$ \\
\hline 11. & Residue & 1.501 & $2.89 \%$ \\
\hline 12. & Glass bottle & 0.321 & $0.62 \%$ \\
\hline 13. & Cans & 0.191 & $0.37 \%$ \\
\hline 14. & Tetra pack & 0.154 & $0.30 \%$ \\
\hline 15. & Leaf & 0.151 & $0.29 \%$ \\
\hline 16. & Plastic spoon & 0.113 & $0.22 \%$ \\
\hline 17. & Iron & 0.05 & $0.10 \%$ \\
\hline 18. & $\begin{array}{l}\text { Hazardous } \\
\text { waste }\end{array}$ & 0.036 & $0.07 \%$ \\
\hline 19. & Wood & 0.033 & $0.06 \%$ \\
\hline \multicolumn{3}{|l|}{} \\
\hline
\end{tabular}

\begin{tabular}{|c|l|c|c|}
\hline No. & $\begin{array}{l}\text { Composition } \\
\text { of SW }\end{array}$ & $\begin{array}{c}\text { Average } \\
\text { (kg/day) }\end{array}$ & \% composition \\
\hline 20. & $\begin{array}{l}\text { Magazines } \\
\text { and } \\
\text { newspapers }\end{array}$ & 0.011 & $0.02 \%$ \\
\hline
\end{tabular}

*Notes: residual SW consists of shoes; sanitary napkins; baby diapers; and others.

Source: (Author, 2020)

Seen in Tab. 4, the composition of SW by category at UAP consisted of $32.29 \%$ biodegradable and $67.71 \%$ non-biodegradable. Food waste came from the kitchen lab and canteen generated $16 \mathrm{~kg} /$ day. This results showed that UAP has a strong compost potential with the 5.6 tons/year or about $32 \%$ of the total average SW generation.

Seen in Tab. 4, the $5^{\text {th }}$ highest composition of SW were food waste $32 \%$; plastic bottles and cups $17.34 \%$; tissue of $13.22 \%$; carton $6.21 \%$; and plastic bags and styrofoam at $5.18 \%$. Compared to other campuses, the composition of SW at Jordan University of Science and Technology (JUST) were plastic $36 \%$, organic $25 \%$, paper $24 \%$, glass $8 \%$, metals $4 \%$, and others 3\% [16]. Furthermore, the Mexicali I campus of the Autonomous University of Baja California had a SW composition: paper and cardboard $43.6 \% ; 6.7 \%$ plastic; $10.2 \%$ organic; $2.5 \%$ metal; $3.6 \%$ glass; $1.8 \%$ construction; $0.3 \%$ hazardous waste; and $31.3 \%$ others [17]. While Universitas Andalas consisted of $26.6 \%$ food waste; garden 9.76\%; wood $1.18 \%$; $25.25 \%$ paper; plastic $30.04 \% ; 1.13 \%$ glass; $1.33 \%$ cans; $0.19 \%$ textile; $0.05 \%$ rubber; $0.12 \%$ metal; and $4.35 \%$ others [15]. Universitas Putra Indonesia Padang consisted of $21.94 \%$ food waste; $5.4 \%$ leaves; $0.39 \%$ wood; $32.8 \%$ plastic; $31.64 \%$ paper; $0.13 \%$ rubber; $0.07 \%$ textile; $1.72 \%$ glass; $1.46 \%$ metal; $0.46 \%$ cans; and $3.58 \%$ others [2]. It could be seen that the composition of SW on campus was dominated by non-biodegradable SW.

According to Damanhuri and Padmi [14], the product packaging was one of factors influence the composition of SW. Observation in canteen 
showed that many package like bottles, plastic, cup, and styrofoam were used to wrap food because of convenience reasons. Even more, the technology development had simplified the delivery of foods affecting to consumption pattern of the campus society. The delivery service activity was related to overpackage issued [18]. For instance, in delivering a meal, it required a container like styrofoam or mica, in addition, plastic bag to ease in handling. Reflecting from the SW composition that dominated by package show the lack of reduce and reuse (2R) applications in daily activity of campus society.

\subsection{Description of campus society participation in $S W$ management at $U A P$}

\subsubsection{Individual internal factors}

An online questionnaire was conducted among 92 respondents consisting of students, lecturers, and administrative staffs to determine their perception and willingness to participate in SW management at UAP. Survey consisted of $47.83 \%$ male and $52.17 \%$ female, randomly selected from different departments. The majority of the respondents were categorized as late teens (18-25 years) 60.87\%, followed by students. Out of 92 respondents dominated by students $56.52 \%$. Evaluations were based on their knowledge, experience, and willingness to participate.

\section{a. Knowledge}

Types of questions and the results of respondents' answers related to knowledge was shown in Tab. 5 .

Table 5. Types of questions and the results of respondents' answers related to knowledge

\begin{tabular}{|l|c|c|c|c|}
\hline \multirow{2}{*}{$\begin{array}{c}\text { Knowledge } \\
\text { Criteria }\end{array}$} & \multicolumn{4}{|c|}{ Respondents' Answers } \\
\cline { 2 - 5 } & Know & $\%$ & $\begin{array}{c}\text { Don't } \\
\text { know }\end{array}$ & $\%$ \\
\hline $\begin{array}{l}\text { Understanding } \\
\text { the 3R concept }\end{array}$ & 88 & $95.65 \%$ & 4 & $4.35 \%$ \\
\hline $\begin{array}{l}\text { Biodegradable } \\
\text { SW }\end{array}$ & 92 & $100 \%$ & 0 & $0 \%$ \\
\hline
\end{tabular}

\begin{tabular}{|l|c|c|c|c|}
\hline \multirow{2}{*}{$\begin{array}{l}\text { Knowledge } \\
\text { Criteria }\end{array}$} & \multicolumn{4}{|c|}{ Respondents' Answers } \\
\cline { 2 - 5 } & Know & $\%$ & $\begin{array}{c}\text { Don't } \\
\text { know }\end{array}$ & $\%$ \\
\hline $\begin{array}{l}\text { Non- } \\
\text { biodegradable- } \\
\text { economics }\end{array}$ & 69 & $75 \%$ & 23 & $25 \%$ \\
\hline $\begin{array}{l}\text { Non- } \\
\text { biodegradable- } \\
\text { residue }\end{array}$ & 62 & $67.39 \%$ & 30 & $32.61 \%$ \\
\hline $\begin{array}{l}\text { Hazardous } \\
\text { waste }\end{array}$ & 81 & $88.04 \%$ & 11 & $11.96 \%$ \\
\hline $\begin{array}{l}\text { How to } \\
\text { manage SW }\end{array}$ & 86 & $93.48 \%$ & 6 & $6.52 \%$ \\
\hline
\end{tabular}

Source: (Author, 2020)

Seen in Tab. 5, the majority of respondents had known knowledge about SW terms, segregation, and ideal management (up to $65 \%)$. While most respondents $(95.65 \%)$ had understood the $3 \mathrm{R}$ concept. On the other hand, most respondents had understood the principles of segregation. In the future socialization about segregation of nonbiodegradable SW according to its economic value (able to be sold to local SW bank).

\section{b. Experience}

The types of questions and answers to respondents regarding their experience was shown in Tab. 6.

Table 6. Types of questions and results of respondents' tires related to the experience

\begin{tabular}{|l|c|c|c|c|}
\hline \multicolumn{1}{|c|}{ Criteria } & Do & \% & Don't & \% \\
\hline $\begin{array}{l}\text { Use } \\
\text { stationery/paper } \\
\text { until they run } \\
\text { out/are damaged }\end{array}$ & 58 & $63.04 \%$ & 34 & $36.96 \%$ \\
\hline $\begin{array}{l}\text { Bring your } \\
\text { cutlery }\end{array}$ & 59 & $64.13 \%$ & 33 & $35.87 \%$ \\
\hline $\begin{array}{l}\text { Bring your } \\
\text { bottle }\end{array}$ & 76 & $82.61 \%$ & 16 & $17.39 \%$ \\
\hline $\begin{array}{l}\text { Bring your } \\
\text { shopping bag } \\
\text { instead of a } \\
\text { plastic bag }\end{array}$ & 55 & $59.78 \%$ & 37 & $40.22 \%$ \\
\hline $\begin{array}{l}\text { Segregate } \\
\text { organic and } \\
\text { inorganic SW }\end{array}$ & 31 & $33.70 \%$ & 61 & $66.30 \%$ \\
\hline $\begin{array}{l}\text { Exchange the } \\
\text { SW into cash } \\
\text { (trash for cash) }\end{array}$ & 25 & $27.17 \%$ & 67 & $72.83 \%$ \\
\hline
\end{tabular}




\begin{tabular}{|l|c|c|c|c|}
\hline \multicolumn{1}{|c|}{ Criteria } & Do & \% & Don't & \% \\
\hline $\begin{array}{l}\text { Make crafts } \\
\text { from used things }\end{array}$ & 21 & $22.83 \%$ & 71 & $77.17 \%$ \\
\hline $\begin{array}{l}\text { Campaigning } \\
\text { friends and the } \\
\text { community to } \\
\text { sort/reuse SW }\end{array}$ & 17 & $18.48 \%$ & 75 & $81.52 \%$ \\
\hline
\end{tabular}

Source: (Author, 2020)

Seen in Tab. 6, the SW reduction was the most preferred minimization method among 3R approach. While, only a minor part experienced segregating and recycling showed by less than $40 \%$ of respondents.

In general, the results showed that the respondent had a good understanding of SW management but lacked the motivation to commit to applying 3R in daily life. According to Bahçelioglu et al. [5], the most crucial factor that demotivates people participating in good practices is that others do not pay enough attention to these practices.

Besides campus society's knowledge, education also plays an important role [8]. In this case, the campus has initiated a campaign program called "Sadar Diri" to educate the campus society to minimize plastic bottles by supply drinking water in a 19-L container on campus. According to the initiator of this program, it was spent 19-L per day. If it assumed that each participant of this program using a $600 \mathrm{~mL}$ bottled (weighed 30 grams) and refiling it, it was estimated that 32 bottles (weighed 960 grams) were reducted to this program. The plastic bottle's average composition resulted in this study was $9 \mathrm{~kg} / \mathrm{day}$, so the reduction percentage was $9,6 \%$.

\subsubsection{Individual external factors}

Analysis of individual external factors using a statistical test of the frequency distribution were as follows:

a. The role of campus

Community-based SW management required both community participation and institution as a motivator and facilitator, in this case, campus management [19]. The result was shown in Tab. 7.

Table 7. Types of campus actions that had been taken and the results of respondents' answers

\begin{tabular}{|l|c|c|c|c|}
\hline \multirow{2}{*}{$\begin{array}{c}\text { Campus Role } \\
\text { Criteria }\end{array}$} & \multicolumn{4}{|c|}{ Respondents' Answers } \\
\cline { 2 - 5 } & Yes & $\%$ & No & $\%$ \\
\hline $\begin{array}{l}\text { Socialization on } \\
\text { SW reduction }\end{array}$ & 20 & $21.74 \%$ & 72 & $78.26 \%$ \\
\hline $\begin{array}{l}\text { Socialization of } \\
\text { SW segregation }\end{array}$ & 16 & $17.39 \%$ & 76 & $82.61 \%$ \\
\hline $\begin{array}{l}\text { Socialization of } \\
\text { SW recycling }\end{array}$ & 17 & $18.48 \%$ & 75 & $81.52 \%$ \\
\hline
\end{tabular}

Source: (Author, 2020)

Seen in Tab. 7, a majority of respondents (up to $70 \%$ ) had not been socialized about 3R. The role of campus in motivating $3 \mathrm{R}$ action was still not optimal.

b. Facilities and infrastructure

Facilities and infrastructure could supported the SW management process on the campus. The campus facilities and infrastructure with the results of the respondents' answers was shown in Tab. 8.

Table 8. Campus infrastructure and facilities as well as the results of respondents' answers

\begin{tabular}{|l|c|c|c|c|}
\hline \multirow{2}{*}{$\begin{array}{c}\text { Facilities } \\
\text { Criteria }\end{array}$} & \multicolumn{4}{|c|}{ Respondents' Answers } \\
\cline { 2 - 5 } & Yes & \% & No & \% \\
\hline $\begin{array}{l}\text { The number } \\
\text { of container } \\
\text { was adequate }\end{array}$ & 54 & $58.70 \%$ & 38 & $41.30 \%$ \\
\hline $\begin{array}{l}\text { Sorting } \\
\text { container } \\
\text { available }\end{array}$ & 5 & $5.43 \%$ & 87 & $94.57 \%$ \\
\hline
\end{tabular}

Source: (Author, 2020)

Seen in Tab. 8, the amount of storage container on the UAP was adequate, but the sorting facilities on the UAP was not available yet. 


\subsubsection{Campus society participation}

Participation is the key to successful 3R implementation due to the SW minimized from the beginning [8]. Segregation participation was also vital if the SW already generated in order to support the recycling process. The perception and willingness to participate in SW management shown in Tab. 9.

Table 9. Participation in SW management and the results of respondents' answers

\begin{tabular}{|l|c|c|c|c|}
\hline \multicolumn{1}{|c|}{$\begin{array}{c}\text { Criteria of } \\
\text { Community } \\
\text { Participation }\end{array}$} & \multicolumn{4}{|c|}{ Respondents' Answers } \\
\cline { 2 - 5 } & Yes & $\%$ & No & $\%$ \\
\hline $\begin{array}{l}\text { The principle of } \\
\text { "reduction" of SW } \\
\text { is efficient in } \\
\text { overcoming the } \\
\text { problem of SW }\end{array}$ & 91 & $98.91 \%$ & 1 & $1.09 \%$ \\
\hline $\begin{array}{l}\text { The principle of } \\
\text { "segregation" of } \\
\text { SW is efficient in } \\
\text { overcoming the } \\
\text { problem of SW }\end{array}$ & 89 & $96.74 \%$ & 3 & $3.26 \%$ \\
\hline $\begin{array}{l}\text { The principle of } \\
\text { "recycling" SW is } \\
\text { efficient in } \\
\text { overcoming SW } \\
\text { problems }\end{array}$ & 84 & $91.30 \%$ & 8 & $8.70 \%$ \\
\hline $\begin{array}{l}\text { Willingness to } \\
\text { reduce SW }\end{array}$ & 88 & $95.65 \%$ & 4 & $4.35 \%$ \\
\hline $\begin{array}{l}\text { Willingness to } \\
\text { segregate SW }\end{array}$ & 89 & $96.74 \%$ & 3 & $3.26 \%$ \\
\hline $\begin{array}{l}\text { Willingness to } \\
\text { "recycle" SW by } \\
\text { exchanging SW } \\
\text { into rupiah }\end{array}$ & 88 & $95.65 \%$ & 4 & $4.35 \%$ \\
\hline
\end{tabular}

Source: (Author, 2020)

Seen in Tab. 9, analyzing the participation level of campus society in SW management was almost all respondents (> 95\%) were willing to participate in SW management at UAP.

\subsubsection{The influence of individual internal and external factors on campus society participation}

Analysis the effect of individual internal and external factors on campus society participation using the chi-square test were as follows: a. The influence of knowledge factors on campus society participation

Provided the chi-square test between knowledge and campus society participation was $\alpha=0.00<0.05$, means that knowledge could affect respondent's participation, because knowledge is strongly correlated with activity.

b. The influence of the respondent's experience on campus society participation

Provided the chi-square test between experience and campus society participation was $\alpha=0.041<0.05$, which means that the experience might affect participation. Experience has a significant relationship with perception of SW management because it is the basic to perceive something.

c. The influence of campus role factors on campus society participation

Provided the chi-square test between the role of the campus and campus society participation was $\alpha=0.313>0.05$, which means that the role of the campus did not affect participation, because it role in terms of socialization or campaign had not been done.

\subsection{Evaluation and recommendations}

UAP is one of the campuses that contributes to SW generation in DKI Jakarta. The results showed that there were no recycle practices on the campus. The SW composition showed that $32 \%$ of biodegradable SW came from food waste, which was compostable [5]. However, research about the composting feasibility study was still required. At the same time, the nonbiodegradables SW (67.71\% of the total SW) were recyclable. The calculation of the recycling potential of $\mathrm{SW}$ at UAP required a recovery factor of each component of the SW shown in Tab. 10.

Table 10. Percentage of recycling of each component of SW 


\begin{tabular}{|c|l|c|}
\hline No. & \multicolumn{1}{|c|}{ SW Component } & \% Recycling \\
\hline 1. & Wet garbage & $69 \%(*)$ \\
\hline 2. & Paper & $50 \%(*)$ \\
\hline 3. & Plastic bags & $50 \%(*)$ \\
\hline 4. & Glass & $65 \%(*)$ \\
\hline 5. & Wood & $10 \%(*)$ \\
\hline 6. & Metal & $80 \%(*)$ \\
\hline 7. & Foam & $0 \%(*)$ \\
\hline 8. & Plastic bottles and cups & $100 \%(* *)$ \\
\hline 9. & Plastic spoon & $40 \%(* *)$ \\
\hline 10. & Packaging & $50 \%(* *)$ \\
\hline 11. & Iron & $100 \%(* *)$ \\
\hline 12. & Tissue & $50 \%(* *)$ \\
\hline 13. & Cans & $100 \%(* *)$ \\
\hline 14. & Hazardous waste & $0 \%(* *)$ \\
\hline 15. & Residue & $0 \%(* *)$ \\
\hline
\end{tabular}

3.5 Strategies for applying the $3 R$ concept in efforts to minimize $S W$ at UAP

Reducing the SW at the source is the first step of the new paradigm hierarchy and coping mechanism. The campus management must decide the target of landfill diversion rate since the existing condition showed almost no diversion rate. Then transform this target into various activities. It is done by developing awareness by the societies among the individuals. Source segregation must be strictly followed through various capacity building and coping mechanisms for getting material for Source: $(*[20]$ and $* *[$ Author, 2020] $)$ recycling and treatment process [21]. Therefore, the campus (university/faculty/study

Plastic bottles and cups were supposed to be $100 \%$ recyclable since pure, transparent plastic could be processed into new products with lower quality. Hazardous waste could not be recycled because explicitly handled by the government. Last, the residue could not be recycled because it could no longer be processed into other products. For this case, a campus can utilize the local SW bank as the intermediary party collecting this recyclable $\mathrm{SW}$ before the further process in a recycling factory.

Table 11. Recycling potential of SW at UAP

\begin{tabular}{|c|l|c|c|c|}
\hline No. & $\begin{array}{c}\text { Recycling } \\
\text { type }\end{array}$ & $\begin{array}{c}\text { Recyclable } \\
\text { (kg/day) }\end{array}$ & $\begin{array}{c}\text { Residue } \\
\text { (kg/day) }\end{array}$ & $\%$ \\
\hline 1. & Composting & 11.57 & - & $22.28 \%$ \\
\hline 2. & Recyclable & 20.111 & - & $38.73 \%$ \\
\hline 3. & Residue & - & 20.242 & $38.99 \%$ \\
\hline
\end{tabular}
program) should arrange some regulations and procedures that show clear consequences and incentives. Besides, a campaign about SW should also be encouraged. Detailed steps of recommendation strategies are shown below.

\subsubsection{Reduce dan Reuse (2R)}

Although the social survey showed that most campus society already understood and applied to reduce and reuse concepts, some programs should be encouraged so that the entire campus has the same commitment and responsibility in SW minimization. The programs are as follows:

a. Minimize the use of the food packaging Various packaging was dominated the compositions at UAP including plastic bottles, cups, bags and styrofoam. So, it is necessary to minimize the packaging with following steps shown in Fig. 4.

Source: (Author, 2020)

Based on Tab. 11, potential SW recycling was $61.01 \%$ consisted of $22.28 \%$ of composting and $38.73 \%$ of recyclable SW and the residue was $38.99 \%$. Observation were conducted to nearest local SW bank accepting and exchanging the recyclable $\mathrm{SW}$ into cash. 


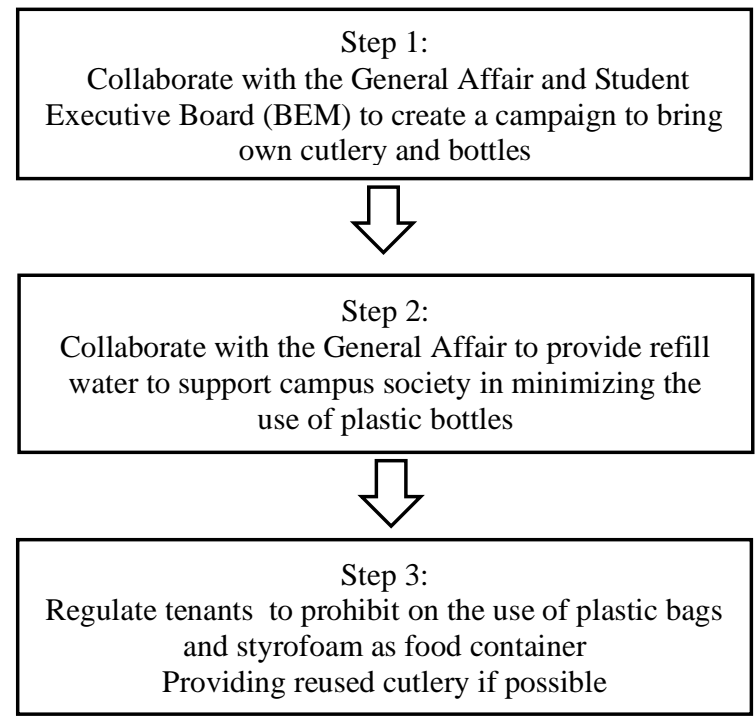

Source: (Author, 2020)

Figure 4. Steps of plastic packaging minimization strategy

b. Minimize the use of carton packaging The composition of carton packaging was the $4^{\text {th }}$ highest $(6.21 \%)$, so it is necessary to minimize carton packaging with the steps shown in Fig. 5.

\section{Step 1:}

Collaborate with the General Affair and the Student Executive Board (BEM) to create a campaign related to bringing their cutlery

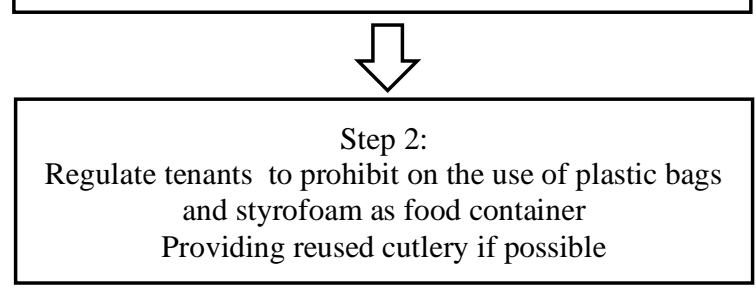

Source: (Author, 2020)

Figure 5. Steps of carton packaging minimization strategy

c. Minimization the use of tissue

The composition of tissue was the $3^{\text {rd }}$ highest $(13.22 \%)$, so the steps to minimize the tissue by increasing the awareness of the campus society shown in Fig. 6.
Step 1:

Collaborate with the General Affair to create a campaign in the toilet and madding related to minimizing the use of tissue:

"Brigging own reusable hankie"

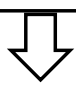

Step 2:

Collaborate with the General Affair to create a campaign on the toilet related to the minimization of tissue usage

Source: (Author, 2020)

Figure 6. Steps of tissue minimization strategy

\section{d. Minimization of paper usage}

The composition of the paper was $3 \%$ to $4 \%$ but still needs to be minimized with the steps shown in Fig. 7.

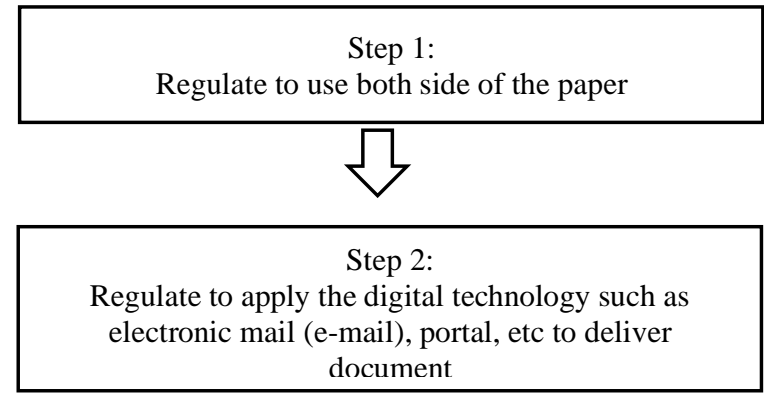

Source: (Author, 2020)

Figure 7. Steps of paper usage minimization strategy

\subsubsection{Recycle $(R)$}

The social survey showed that most respondents did not experience recycling. Besides, there was no SW segregation facility at UAP. In applying this concept, it is necessary to provide a sorting center located in the SW collecting room and firstly supported by a responsible administrator. As the awareness increases, it can be spotted in some other areas considered as the primary SW generation source. Then, the collected recycling SW will be exchanged to the local SW bank for some cash. The steps to minimize $\mathrm{SW}$ in recycling are shown in Fig. 8. 


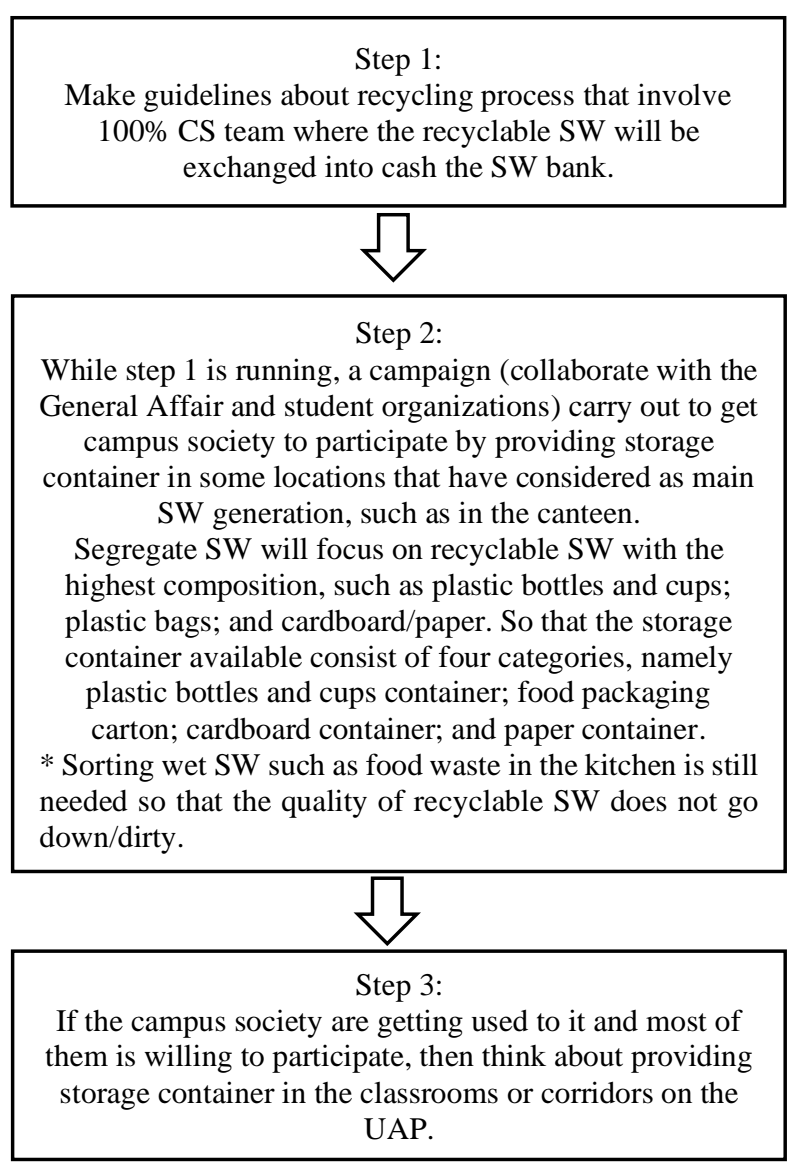

Source: (Author, 2020)

Figure 8. Steps of recycling minimization strategy

Regarding the step 1 strategy shown in Fig. 8, the economic potential of the recyclable SW can be calculated based on the amount of SW generated on the UAP. The economic potential of recyclable SW based of local SW bank near campus is shown in Tab. 12.

Table 12. The economic potential of recyclable SW

\begin{tabular}{|c|l|c|l|l|}
\hline No. & $\begin{array}{c}\text { SW } \\
\text { component }\end{array}$ & $\begin{array}{c}\text { SW } \\
\text { generation } \\
\text { (kg/day) }\end{array}$ & $\begin{array}{c}\text { Price per } \\
\text { kg }\end{array}$ & $\begin{array}{c}\text { The selling } \\
\text { price of } \\
\text { SW }\end{array}$ \\
\hline 1. & HVS & 2.387 & Rp. 1,500 & Rp. 3,581 \\
\hline 2. & $\begin{array}{l}\text { Brown } \\
\text { paper }\end{array}$ & 1.580 & Rp. 400 & Rp. 632 \\
\hline 3. & $\begin{array}{l}\text { Magazines } \\
\text { and } \\
\text { newspapers }\end{array}$ & 0.011 & Rp. 2,000 & Rp. 23 \\
\hline 4. & Carton & 3.226 & Rp. 400 & Rp. 1,290 \\
\hline 5. & Cardboard & 2.530 & Rp. 1,500 & Rp. 3,795 \\
\hline
\end{tabular}

\begin{tabular}{|c|l|c|c|c|}
\hline No. & $\begin{array}{c}\text { SW } \\
\text { component }\end{array}$ & $\begin{array}{c}\text { SW } \\
\text { generation } \\
\text { (kg/day) }\end{array}$ & $\begin{array}{c}\text { Price per } \\
\text { kg }\end{array}$ & $\begin{array}{c}\text { The selling } \\
\text { price of } \\
\text { SW }\end{array}$ \\
\hline 6. & $\begin{array}{l}\text { Plastic } \\
\text { bottles and } \\
\text { cups }\end{array}$ & 9.001 & Rp. 3,000 & Rp. 27,000 \\
\hline \multicolumn{3}{|c|}{ Total (Rp.) } & Rp. 36,281 \\
\hline
\end{tabular}

Source: (Author, 2020)

Tab. 12 shows that the selling price of recyclable SW at the nearest local SW bank is Rp. 36,281/day. If accumulated in a month, the exchange cash will reach Rp. 1,088,430/month. The cash can be managed to sustain programs related to environmental sustainability, such as supporting the "Sadar Diri" program, funding other campaign programs, or providing incentives for cleaning officers to sort the SW. The SW can be exchanged to the North Tanjung Duren SW Bank that receives recyclable SW from any sector around North Tanjung Duren, including housings, individuals (collectors), and education institutions (schools and campuses). The procedure for exchange SW is quite simple by dropping directly or pick up requests with no additional fee for the SW already sorted. For this reason, it is essential to sort the SW at the source.

This segregation is one aspect of SW management that supports the concept of a green campus. The green campus concept application is a challenge that requires a longterm commitment from the entire campus society. According to the EPA, this effort will provide benefits in terms of environmental and economic sustainability, experiences expected to be applied in real life; and improving the quality of life on campus. The transformation into better SW management may not be immediate but gradual, depending on the management and society's readiness.

\section{Conclusion}

The SW generation on the UAP averaged 52.63 $\mathrm{kg} /$ day. At the same time, the $\mathrm{SW}$ generation factor was $0.08 \mathrm{~kg} /$ person/day. The $\mathrm{SW}$ 
composition by its category on the UAP consisted of $32.29 \%$ biodegradable and $67.71 \%$ non-biodegradable. In contrast, the 3rd highest composition of SW based on types were food waste $32 \%$; plastic bottles and cups $17.34 \%$; and tissue $13.22 \%$. The social survey pointed out that campus society has a positive perception and willing to participate in future SW management. On the other hand, educational activities and communication (such as socialization and posters) are necessary to make them a part of the sustainable campus studies. Regulations and procedures should support their activities.

Based on the research above, the strategies that can be implemented on the UAP was the implementation of the $3 \mathrm{R}$ concept regarding decrease the SW generation rate, increase the recyclable material collection rate, and increase social participation level.

For the SW management plan's sustainable application, monitoring of SW generation should be continued and reported regularly to evaluate the SW minimization achieved by applying the plan. Last, the recovery of food waste in UAP by analyzing the compost potential should be conducted in further research since it was relatively high in SW composition.

\section{Acknowledgement}

This study was supported by Yayasan Pendidikan Agung Podomoro. The authors also thank General Affair UAP who helped in the data collection process.

\section{References}

[1] Anne AE, Study of waste generation and composition as a basis for the design of waste collection systems in the campus area of the Universitas Indonesia (case study: 4 faculties and 1 facility on the Universitas Indonesia). Depok: Faculty of Engineering Universitas Indonesia; 2011. (in Bahasa Indonesia).

[2] Dewilda Y, Julianto J. Assessment of waste recycling, composition, and potential as a basis for waste management in the campus area of the Universitas Putra
Indonesia. Nat Sem on Develop of Sustain Region and City 2019: 1 (1):142-51. (in Bahasa Indonesia).

[3] Banaget CK, Boedi GS, Kristanto A, D IG. Characteristics and potential of waste recycling in the Universitas Indonesia (case study: faculty of social and political sciences). Depok: Faculty of Engineering Universitas Indonesia; 2013. (in Bahasa Indonesia).

[4] Ebrahimi K, North LA. Effective strategies for enhancing waste management at university campuses. Intl J of Sustain in Higher Educ 2016.

[5] Bahçelioğlu E, Buğdaycı ES, Doğan NB, Şimşek N, Rich S, Alp E. Integrated solid waste management strategy of a large campus: A comprehensive study on METU campus, Turkey. J Clean Prod 2020; 265.

[6] Tangwanichagapong S, Nitivattananon V, Mohanty B, Visvanathan C. Greening of a campus through waste management initiatives: Experience from a higher education institution in Thailand. Int J Sustain High Educ 2017: 18 (2): 203-17.

[7] Damanhuri E, Padmi T. Integrated Waste Management. Second Edition. Bandung: ITB Press; 2015. (in Bahasa Indonesia).

[8] Dhokhikah Y, Trihadiningrum Y, Sunaryo S. Community participation in household solid waste reduction in Surabaya, Indonesia. Resour Conserv Recycl 2015: 102 (09): 153-62.

[9] Fatmawati S, Syahbana JA. Implementation of sustainable development policy in the campus environment (comparative study between Universitas Diponegoro at Tembalang and Universitas Nantes at Tertre). A Wil City Builder 2015: 11 (4): 484. (in Bahasa Indonesia).

[10] Buana RP, Wimala M, Evelina Ri. Development of indicators for the participation of college management in implementing the green campus concept. Racana Reka 2018: 4 (2): 82-93. (in Bahasa Indonesia).

[11] Hapsari ID, Sumarjiyanto BM N, Purwanti EY. Sustainable campus planning and budgeting: Universitas Diponegoro green campus. Technique. 2014: 35 (2): 8693. (in Bahasa Indonesia).

[12] Tansatrisna D. Community Perception and Participation in Household Waste Management. Bogor: Faculty of Human Ecology Institut Pertanian Bogor 2014: 1-24. (in Bahasa Indonesia).

[13] Ifegbesan AP, Ogunyemi B, Rampedi IT. Students' attitudes to solid waste management in a Nigerian University: implications for campus based sustainability education. Int J of Sustain in High Educ Information 2012.

[14] Damanhuri E, Padmi T. Waste Management. Bandung: ITB Press; 2015. (in Bahasa Indonesia).

[15] Ruslinda Y, Raharjo S, Susanti L. Study of the application of the concept of integrated waste management in the campus environment of Universitas Andalas. Pros SNSTL I 2014: 202-206. (in Bahasa Indonesia). 
[16] Qdais HA, Saadeh O, Al-Widyan M, Al-tal R, AbuDalo M. Environmental sustainability features in large university campuses: Jordan University of Science and Technology (JUST) as a model of green university. Int $J$ Sustain High Educ 2019: 20 (2): 214-28.

[17] de Vega CA, Benítez SO, Barreto MER. Solid waste characterization and recycling potential for a university campus. Waste Manag 2008: 28.

[18] Song G, Zhang H, Duan H, Xu M. Packaging waste from food delivery in China's mega cities. Resour Conserv Recycl 2018: 130 (11): 226-7.

[19] Suryani AS. The role of waste bank in the effectiveness of waste management (case study of waste bank Malang). Aspiration 2014; 71-84. (in Bahasa Indonesia).

[20] Wardiha MW, Putri PSA, Setyawati LM, Muhajirin. Waste generation and composition in office and wisma area (case study: Werdhapura Village Center, Denpasar, Bali). J Precipitation 2013: 10 (1): 7-17. (in Bahasa Indonesia).

[21] Rajamanikam R, Poyyamoli G, Student PD, Venkataraman Nagar R. Towards zero-waste campus: compositional analysis of solid waste at the staff quarters to frame inclusive sustainable campus waste management system. Int $J$ Innov Res Science Engineering 2014; 3 (4).

[22] Mawonde A, Togo M. Implementation of SDGs at the University of South Africa. Int J of Sustain High Educ 2019: 20 (5): 932-950. 